\title{
THE JUDICIARY AND THE SURVIVAL OF DEMOCRACY IN NIGERIA Analysis of the 2003 and 2007 Elections $^{1}$
}

\section{David U Enweremadu}

\author{
David U Enweremadu is a lecturer in the Department of Political Science, \\ University of Ibadan \\ e-mail: uchennadave@yahoo.com
}

\begin{abstract}
For many Nigerians, and indeed in the eyes of most foreign observers of Nigerian affairs, the restoration of democratic rule in Africa's largest country in May 1999 has brought little or no change in the politics of this vast nation of 150-million people. Corruption, electoral malpractice and political violence, the usual causes of governmental instability, have remained intractable despite a deluge of reform initiatives. Yet, as this article will show, while the benefits of most institutional reforms have been difficult to measure, there has been significant progress in a few other key areas of national political life. One of them is the relatively successful reform of the judiciary, which has led to the institution's gradual emergence as a courageous and impartial arbiter in intra-elite electoral disputes in this chronically unstable federation. The transformation of the judiciary is amply demonstrated by the large number of judicial pronouncements that have upturned the results of several flawed elections and restored to office elected officials, such as state governors, wrongfully removed from their positions. This article argues that these decisions and the new activist role of the judiciary which produced them have, in many ways, helped to reinforce the role of the judiciary as a vital instrument of political control and democratic stabilisation and by so doing have helped to prolong the life of Nigeria's Fourth Republic.
\end{abstract}

1 The author acknowledges the generous funding provided by Tracking Development Project for this study, which was undertaken in October-December 2009, as well as the invaluable suggestions and comments of both the anonymous reviewer and Drs Akinyinka Akinyoade and Jan Kees van Donge of the African Studies Centre, University of Leiden, The Netherlands. Special thanks also go to Mr Sola Fasure and all the library staff of The Nation Newspapers (Lagos) for providing the author with access to their newspaper cuttings and other materials. 


\section{INTRODUCTION}

On 29 May 2009 Nigerians from all walks of life trooped out in their millions to mark their country's tenth year of uninterrupted democratic rule. This was no mean feat. During many of the past 49 years Nigeria's political history had been dominated by fraudulent elections, violent political conflict and military coups. The country's two previous attempts at civilian-to-civilian transitional elections (1960-66 and 1979-83) were both dogged by allegations of massive fraud and violence, before they were cut short by military coups (Lewis 2003).

As soon as the results of these elections were announced defeated political aspirants rushed to denounce them, while manipulating their political thugs and supporters to unleash violence and mayhem on their perceived opponents. When such tactics failed they issued open invitations to the military to seize power and disband all democratic structures, as a way of punishing their rivals. Thus, despite open professions of commitment to the idea of democracy, elections and political power were perceived as do-or-die affairs. The practice of resorting to the law courts to resolve electoral or political disputes was thought to be a fruitless venture, especially where the courts were perceived to be biased in favour of incumbents.

Since the return to democratic rule on 29 May 1999, however, some major behavioural shifts seem to have occurred among Nigerian politicians. While some continue to practice violence and political thuggery many others now prefer to use judicial channels to resolve their conflicts. More importantly, these politicians are also learning to accept the decisions of the courts as final, whether or not they are in their favour.

These radical changes spring largely from transformation within the judiciary itself, which has, since 1999, been encouraged to play an increasingly assertive role as a courageous and impartial arbiter in the country's democratic politics in general and its electoral disputes more specifically. The clearest evidence of this fact is the increasing number of judicial decisions that have upturned the results of several rigged elections, mainly in favour of opposition parties or individuals opposed to the federal government, led by the Peoples Democratic Party (PDP). The transformation of the Nigerian judiciary has also been underlined by some other judicial pronouncements which restored state governors wrongfully removed from office in the course of disagreement with the federal government or political godfathers.

While acknowledging that there have also been controversies over some cases handled by the judiciary, especially in terms of contradictions between the pronouncements of the lower and higher courts on similar or identical cases, which, in some cases, may not be unconnected with the corrupt tendencies of 
some judges, this paper argues that as a result of the decision of many Nigerian politicians to embrace the judiciary as a reliable arbiter of political conflicts the courts are indeed becoming an instrument of democratic advancement and stability in the Fourth Republic. In a nutshell, therefore, this article discusses the factors responsible for the change in the attitude of the Nigerian political class and courts and the extent to which the change has contributed to stabilising politics and democracy since 1999.

The analysis begins with a historical review of the Nigerian judiciary before 1999. That is followed by a summary and discussion of recent reforms in the judiciary, which, we believe, are at the root of these changes. The following section reviews the political consequences of these reforms in terms of the judiciary's involvement in democratic stabilisation. This is done through a review of some selected landmark cases arising from the 2003 and 2007 elections. The conclusion presents a brief summary of the findings of the study.

\section{THE JUDICIARY IN THE PRE-1999 ERA: AN OVERVIEW}

The stability and quality of a democratic constitution is often determined by the degree of importance a society attaches to the judiciary and the powers it gives to it (Mbanefo 1975). This can be measured in several ways. The first is whether the judiciary is independent, that is, if it is not beholden to any special interest or to either of the other two arms of government (executive and legislature).

As Davies points out, the independence of the judiciary is desirable in any organised society that cherishes the idea of the rule of law and human freedom and, in order to ensure this, the appointment, promotion and dismissal of judges are usually placed in the hands of a neutral body such as a national judicial commission whose members are paid through a special fund (Davies 1990). The competence and integrity of the Bench is the second criterion. Judges must be competent, learned and of high integrity in order to command universal respect and approval.

A third factor is the availability of adequate facilities and personnel, that is, whether there are sufficient judges and courts to meet the needs and demands of the public (Davies 1990).

All indications are that before 1999 Nigeria's judiciary was not defined by any of these factors. While a detailed analysis of the character and operations of the judiciary before 1999 is beyond the reach of this chapter, the point can still be made that the Nigerian bench before that time was beset by a number of challenges (Oko 2002; 2005). One of the key challenges was the lack of independence arising from the judiciary being tied to the apron strings of the executive arm 
of government, which, by a variety of means, including the process of selecting judges (appointments, promotion and conditions of service) and the deft use of pliable judges to execute unpopular agendas, made the judiciary more or less the government's rubber stamp (Otteh 2004; Nwabueze 1992).

A second problem was the credible evidence of widespread sectional bias and corruption within the bench (Federal Republic of Nigeria 1994; 2003). These shortcomings, and many others, notably the issue of inadequate judges and the inability to deliver judgements in good time, encouraged potential litigants to seek out extra-constitutional means of securing justice (UNODC 2003; 2004). For instance, during the first (1960-1966) and second (1979-1983) republics several appeals or election petitions brought before Nigerian courts by aggrieved political aspirants ended in controversial decisions (Abdul-Razaq 2005). These helped to stoke political violence and, ultimately, bloody military interventions.

Under this arrangement the capacity of the judiciary to mediate in conflicts, especially election disputes and, by so doing, to help maintain democratic stability, was increasingly undermined. As a number of studies will show, these problems were later compounded by Nigeria's long experience with military dictatorship (Nwabueze 1992).

Beyond its inability to mediate conflicts, the neglect and politicisation of the judiciary transformed this important institution in several other negative ways.

One of these was that the judiciary became an anti-democratic institution. That is to say that, contrary to its democracy enhancing role, it became a potent tool for undermining democracy and fostering authoritarian rule (Davies 1990) to such a degree that it has been blamed for the collapse of the second and third civilian republics.

During the Second Republic, for instance, petitions emanating from the two general elections held during the period flooded the courts and elections tribunal (Olurode 1990). But rather than do justice to these petitions the courts appeared bent on ensuring the status quo and not disturbing the balance of political power among the various contenders (Unobe 1990). Frustrated by the courts, several politicians resorted to calling on the military to intervene. This call was eventually heeded on the night of 31 December 1983, when the military struck, putting an end to Nigeria's second civilian regime.

Similarly, the annulment of the 12 June 1993 presidential election, which was supposed to have concluded the transition to Nigeria's Third Republic, was facilitated by the inglorious role of the judiciary. The drama began when Justice Bassey Ikpeme of the Abuja High Court granted an interim injunction stopping the conduct of the presidential polls. This order came only two days before the election and was given despite an existing law barring the courts from entertaining suits relating to the elections. More importantly, the ruling was in response to a 
suit instituted by the Association for a Better Nigeria (ABN), led by a controversial politician, Arthur Nzeribe, who was a well-known advocate of military rule.

Although the National Electoral Commission (NEC) disobeyed the ruling on the grounds that Section 37 of the Transition to Civil Rule Decree ousted all court rulings on the conduct of an election, the action of the courts gave then military ruler, General Ibrahim Babangida, sufficient reason to annul the elections (Agbo 2008).

From the above it is clear that Nigeria's pre-1999 judiciary did not enjoy a smooth course as a democracy enhancing institution. Instead it was often caught in contradictory trajectories between vulnerability in practice and independence in theory. These developments, as Omotola argues, may not be unconnected with the prebendal character of the Nigerian state, prolonged military rule, and the attendant weak institutionalisation of democratic political institutions and culture (Omotola 2007c).

\section{THE 1999 TRANSITION AND THE TRANSFORMATION OF THE JUDICIARY}

Soon after Nigeria completed her transition from military to civil democratic rule in May 1999 its judiciary became enmeshed in a gigantic corruption scandal which culminated in the sacking of several senior judges. Between 1999 and 2004 alone at least five senior judges were dismissed for corruption and abuse of power, following investigations by the National Judicial Council (NJC) (Newswatch, 9 February 2004).

The increasing corruption among Nigerian judges, including judges of superior courts who were thought to be relatively immune from graft, immediately became an issue of national concern. Yet these developments could not obscure the improving level of independence and integrity of Nigerian courts and judges, which had suffered greatly under the country's preceding military regimes (Otteh 2004; Nwabueze 1992; Oko 2005; Federal Republic of Nigeria 2003). Indeed, one can reason that many of the sanctions (suspension and dismissal) applied against corrupt judges since 1999 had been the result of specific reform initiatives which have converged to take the judiciary from its position of relative political obscurity at the beginning of 1999 to one of national prominence by the end of 2009 .

Three of these reform initiatives are worthy of more detailed mention. The first relates to some unique provisions introduced by the 1999 Constitution, especially those providing for the establishment of two independent regulatory institutions, the NJC and the Federal Judicial Service Commission (FJSC). Chapters 20(a) and 21(a) of the Third Schedule of the Constitution empower the NJC to investigate judges accused of wrongdoing and recommend appropriate sanctions 
to the president and commander-in-chief of the state governors in the case of a judge of a state court. The body is also charged with recommending judges for appointment and promotion and enforcing the procedures laid down for judges, especially the Code of Conduct for Judicial Officers of the Federal Republic of Nigeria.

Similarly, judges are to be appointed by the president, not only subject to Senate confirmation but also on the basis of the recommendation of the NJC, which, itself, receives advice or nominations from the FJSC. According to s 158(1) 'the National Judicial Council shall not be subject to the discretion or control of any other authority or person' (Federal Republic of Nigeria 1999). The FJSC, on the other hand, oversees the general welfare of members of the judiciary. In order to guarantee their independence the composition of both bodies is largely independent of the executive and legislative arms of government. Thus, both institution are headed by the chief justice of Nigeria (CJN) and comprise some of the most senior members of the Nigerian Bench and Bar, plus some representation from outside the legal profession. As Suberu (2008) observes aptly, despite criticisms that these bodies represent an assault on Nigeria's federal system they have, since 1999, functioned relatively well to promote judicial independence and integrity.

The second source of transformation came from the judiciary itself, in terms of the personal commitment of successive CJNs, notably Justice Mohammed Uwais, who was the country's chief justice from December 1995 to June 2006 (Suberu 2008). Throughout his tenure Justice Uwais was committed to the idea of judicial integrity and independence. For instance, under his leadership Nigerian judges adhered substantially to both the Code of Conduct for Judicial Officers of the Federal Republic of Nigeria, a nationally prescribed code, and the Bangalore Principles of Judicial Conduct of 2002, an international judicial code of which the Nigerian judiciary, under Chief Justice Uwais was one of the major initiators. As a consequence, Nigeria participated actively in all the stages leading to the adoption of the code in April 2000 in Vienna. Justice Uwais also embraced the numerous administrative reforms championed by some international bodies (UNODC 2003b), in collaboration with the rest of the leadership of the judiciary, which helped to raise the integrity and efficiency of Nigerian courts.

The third factor that enhanced the transformation of the Nigerian judiciary was the unprecedented vigilance and heightened awareness of the public, especially court users (lawyers and their clients), civil society groups, human rights advocates, democracy activists and politicians, particularly those from the opposition parties. Taking advantage of the current liberal political and constitutional environment these groups have increasingly monitored the activities of judges and have, in many instances, raised the alarm when traces of corrupt practices or abuse of powers were found. Consequently, some of their petitions have led to the launching 
of several investigations, many of which culminated in the retirement or outright dismissal of scores of judges. As is to be expected, most of these retirements related to matters involving election petitions (Enweremadu 2006).

How, then, did these three factors interact to take the judiciary from a position of relative political obscurity at the beginning of 1999 to one of national prominence a few years later? How did the changed role of the judiciary contribute to the stabilisation of democracy? In our view, one way of answering these questions may be to look at the role of the judiciary in the management of some key postelection disputes and the resultant changing attitudes of Nigeria's political class towards the courts and the legal process.

The analysis presented here is structured in two parts. The first focuses on the judicial review of some election and political disputes that followed the 2003 vote. The second examines the judicial resolution of selected electoral disputes traceable to the highly disputed 2007 general elections. During the period under review (1999-2009) Nigeria held three national elections (1999, 2003 and 2007). All electoral or political disputes emanating from the military-supervised 1999 transitional election are excluded from our analysis because of their less polarising nature and the limited role played by the judiciary during and after the vote.

\section{THE JUDICIARY AND THE 2003 ELECTION}

Although the prospect of a general election has always been a source of panic in Nigeria the stakes in the 2003 election were particularly high. There were three reasons for this. The first was that a successful election would represent Nigeria's first civilian-to-civilian transition, potentially leading to the longest period of civilian democratic rule in the country's history. Secondly, successful conduct of the elections, it was thought, would permit Nigeria to consolidate its rising diplomatic profile and the economic clout made possible by its return to the committee of democratic nations and its soaring oil revenues. Thirdly, and perhaps most importantly, in a decentralised political system victory in the elections, especially the gubernatorial elections, held the possibility of increased access to massive financial resources, especially for would-be governors of the nine oil-rich Niger Delta states, who looked set to profit from the sharp increase in the international price of crude oil and the decision of the federal government in early 2000 to begin to implement existing constitutional provisions on derivation, requiring the payment of 13 per cent of all oil receipts to oil producing states in relation to their productive capacities (The Sun, Lagos, 8 May 2006).

But the assumed importance of an election will not, on its own, translate into success. In the case of the 2003 elections success depended on a number of other factors. One was whether political parties and their candidates would 
live up to the 'Code of Conduct for Political Parties', eschew political violence and intimidation and commit to open and fair campaigning (Jeter 2003). More importantly, success also depended on the capacity and willingness of the managers of Nigeria's electoral system, especially the Independent National Electoral Commission (INEC), to deliver a relatively clean, that is, free and fair election. This implies an election whose outcome is such that most participants will perceive the results as reflecting the wishes and aspiration of the voters and that, where this is not the case, there is a capable and honest judiciary to attend to the grievances of the losers.

The 1999 Constitution provided for judicial outlets for the resolution of such grievances, which, as indicated above, have been complemented by institutional reforms aimed at insulating the judiciary from politics and political influences, as well as the decision to retain existing safeguards against the ethnicisation of the legal system.

Although Nigeria is a federal state its judicial architecture remains unitary in nature. Depending on the issue at stake appeals typically emanate from the magistrates, customary and sharia courts, or from the Federal High Court, State High Court, State Customary AC and State Sharia Court Of Appeal. They then go on to the Federal AC, before terminating at the Federal Supreme Court.

All election complaints, except those pertaining to a presidential election, must first be heard by State Election Petition Tribunals (SEPTs), to be constituted by the president of the Federal AC and established in all 36 state of the federation. Petitioners who are dissatisfied with the decisions reached by the SEPTs can appeal to the Federal AC, which has the final say in all matters relating to all elections, except presidential elections. Petitions relating to presidential elections, on the other hand, will first be heard by the Presidential Elections Tribunal (equivalent to a federal AC) sitting in Abuja. Further appeals will go straight to the Federal Supreme Court, which is the highest court in the land. Both courts are to be constituted by the chief justice of the federation. While this judicial structure may reflect the centrist proclivities of its military promulgators (Suberu 2008), the important point, as we shall see in our analysis of some of the most important petitions brought before the courts after the 2003 elections, is that it has worked relatively well to secure the neutrality and independence of and respect for the judiciary.

\section{Stormy preparations and a flawed election}

Arrangement for the epic elections of 2003 began several months before voting day in April. In total 64-million voters were registered at some 120000 polling booths (Obassa 2003). Additional political parties were also registered, taking 
the number from just three in 1999 to 30 in 2003 (Aderibigbe 2001). This greatly expanded the political space and increased competition, but, at the same time, it fragmented the political class and opened new channels for potential conflict. Several months before the elections INEC began to put the necessary logistics in place. But despite all these efforts the elections were marked by violence, including high-profile political assassinations, thuggery and constant harassment of political opponents, especially during the run-up (Ologbenla 2003).

The 2003 elections brought a number of new challenges. Firstly, the sheer number of political aspirants and parties participating meant there was bound to be an extremely high number of post-election petitions. Secondly, unlike the 1999 transitional election supervised by a departing military regime, which, itself, was not a direct participant, almost all the candidates at all levels in the 2003 elections were incumbents running for re-election.

The result was that the propensity to engage in electoral fraud would probably be particularly high and the judiciary, especially the judges who were scheduled to hear election petitions, were likely to come under unprecedented pressure to deliver 'politically' correct judicial decisions. Another source of worry was doubts about the capacity of INEC to cope with the political and logistical challenges involved in organising both federal and state elections.

In a bid to dampen tension and ensure a more manageable election INEC decided to stagger the elections. All legislative elections were fixed for 12 April, while presidential and gubernatorial elections were reserved for 19 April. The dates proposed by INEC coincided with the Easter holidays, sparking calls for the elections to be postponed. Indeed, one political party went to court, seeking to compel INEC to postpone the elections. The court ruled that such a postponement would be incompatible with both the Constitution and the 2002 Electoral Act, which stipulated that elections must be held at least 60 days before the expiry of the tenure of elected officials. The strategy adopted by INEC and its doggedness paid off. The elections proved less violent than widely expected. Despite this, INECs efforts were not sufficient to make the vote credible or acceptable.

Like previous Nigerian elections the 2003 poll was characterised by massive vote-buying, ballot-box stuffing and intimidation of voters. A number of new forms of irregularity emerged. One of these was changing the names of candidates on party lists submitted to INEC in Abuja, replacing them with those of individuals who had neither won primary elections within their political parties nor were known to be candidates. The result was that individuals who had not even stood in the election were declared elected (Ogunsanwo 2006). While all the parties were involved in such acts the PDP led the field.

A second challenge arising from the conduct of the 2003 election was the outbreak of potentially destabilising intra-elite disputes, such as disagreements 
between some elected officials and their godfathers (ie, financiers) over the modalities for sharing power and, by implication, public resources, as well as the attempts to employ the then fledgling anti-corruption programme as a tool for the elimination of political rivals.

As the date set for the 2007 elections approached these conflicts assumed even more dangerous dimensions, as the Constitution was routinely ignored by some of the key actors in their desperate bid to bring down their perceived political enemies. In many states political disputes escalated into impeachment proceedings launched against several embattled state governors. The task of righting some of the wrongs of the severely flawed 2003 election, as well as resolving the disputes emanating from the attempted removal of elected officials without recourse to guidelines set out in the Constitution, ultimately fell on the shoulders of the judiciary, now seen as the last hope of the politically oppressed.

\section{THE SPECTRE OF INTRA-ELITE DISPUTE: THE JUDICIARY AS MEDIATOR}

The scale of malpractices observed during the election was confirmed by the number of complaints to the judiciary that arose from the elections. In all, 527 petitions were received in respect of the 2003 elections (The Punch, 10 February 2009), covering all categories of elections. A number of lawsuits were also lodged with the various courts over the legality or otherwise of the procedures adopted in seeking to effect the removal of some elected officials, notably state governors, in several key states. The question on every tongue was whether the judiciary was sufficiently prepared to act to save Nigeria's democracy by upholding justice and rule of law? Or would it, as in the past, side with the highest bidder and the powers that be?

As it turned out, the courts were well disposed to use their powers to help advance justice and democracy. Thus, while most of the petitions brought before the courts failed, mainly for lack of evidence (The Guardian, 10 July 2004) and there were serious levels of corruption among some Nigerian judges, notably judges of the lower courts, a few landmark decisions were taken by the higher courts which tended to suggest that Nigeria might have entered a new era of judicial independence and preeminence. Three cases were particularly important.

\section{The governorship elections in Anambra State: Governor Chris Ngige vs Peter Obi}

The election in Anambra state was officially won by the ruling PDP, which also controlled the state from 1999 to 2003, under former governor Chiwonke 
Mbadinuju. The party's flag-bearer in that election was Chris Ngige. Mbadinuju lost the PDP ticket for re-election in 2003 to Ngige after falling out with his local godfather, Sir Emeka Offor, and the leadership of the party, based in Abuja. But the new PDP governor, Chris Ngige, had himself been sponsored by a local godfather, Chris Uba, a multibillionaire businessman with strong links to Abuja. Thus, soon after his inauguration in May 2003, Ngige, like Mbadinuju, faced several challenges to his position.

These challenges initially came from Ngige's self-proclaimed godfather who, vexed by his increasingly independent approach to governance, tried unsuccessfully to kidnap him and force him out of office (Ologbenla 2003). Ngige will face an even more daunting challenge from his closest rival in the governorship race, Peter Obi of the APGA. Obi filed a petition with the Anambra State Elections Petition Tribunals (ASEPT) immediately after the 2003 elections, challenging the purported victory of Chris Ngige. His argument was that he and not Ngige had won the election. While Obi's petition was being considered Ngige's godfather confessed that he had helped Ngige rig the 2003 governorship election based on a pact between the two former allies. Ngige himself gave interviews suggesting he was not very confident of his election. In one he said:

If we are taken to the tribunal we shall also cross swords with them because we have evidence of electoral malpractices against them. We are trying to carry out a cross litigation if Peter Obi fails to accept our right hand of fellowship. But if he keeps quiet we will extend our right hand of fellowship to him and ask him and the rest to come over. Otherwise my simple advice is that those who live in glasshouses should not throw stones.

The Guardian, 7 June 2003

The fraudulent nature of Ngige's victory was, therefore, never in doubt. Nor was the tendency towards the criminalisation of politics in Anambra State, brought about by the phenomenon of godfathers in Nigerian politics. The problem of godfathers was not unique to Anambra State. It had taken hold in several Nigerian states (Omotola 2007a), had become a popular topic for academics, and was widely debated in the media. But curiously nothing was done about it. In the case of Anambra State the problem could only be corrected by a court (the ASEPT), which, on 12 August 2005, after nearly two years of hearings, overturned INEC's decision and declared Peter Obi the authentic winner of the 2003 Anambra gubernatorial election. This decision would later be upheld by the Court of Appeal (CofA), thus putting a stop to all the desperate attempts by some godfathers within the PDP to take over Anambra State at all costs. 


\section{A tainted impeachment: \\ Governor Rashidi Ladoja vs Oyo State House of Assembly}

Apart from the issue of godfathers another defining feature of the Obasanjo presidency (1999-2007) was the constant friction between the legislature and the executive at all levels of government, manifesting in several cases of impeachment. As with godfather related conflicts these legislature-executive frictions were usually rooted in the personalisation and monetisation of politics.

The Oyo case, arguably one of the most controversial, was triggered on 12 January 2006 when the elected governor of Oyo State, Rashidi Ladoja, was impeached by the Oyo State House of Assembly, dominated mainly by legislators from his own PDP, and was immediately replaced with his deputy, Christopher Alao-Akala. Before his impeachment Governor Ladoja was locked in a mortal power struggle with a local power broker and his own godfather, Lamidi Adedibu, who enjoyed the loyalty of most members of the state assembly. Thus, even though Ladoja's removal was premised on specific allegations of corruption and abuse of office, in reality, the fight, like that between Ngige and his godfather, Chris Uba, in Anambra State, actually centred on the modalities for sharing public offices and resources, as agreed during a pre-election pact (Omotola 2007c).

Even though Ladoja's impeachment was not the first under the Fourth Republic - in 2005 Governor DSP Alamieyeseigha of Bayelsa State had been impeached by the Bayelsa State House of Assembly after jumping bail in Britain, where he was facing charges of money laundering - he decided to challenge the move before an Oyo State High Court sitting in the city of Ibadan. After hearing his appeal the lower court upheld the impeachment, forcing him to file an appeal to the CofA in Ibadan.

On 1 November 2006 the CofA nullified his impeachment and ordered that he be reinstated immediately. The court held that the impeachment process was illegal and unconstitutional and was therefore null and void.

In the opinion of the court the process was faulty on several counts - the legislators had sat in an hotel rather than in the State House of Assembly, the notice of impeachment had been delivered through the newspapers, only 18 not 22 legislators had been present, an affidavit of suspension had been unavailable, the time-frame of the process was flawed and the High Court did not have jurisdiction. Thus, here, as in the case of Anambra, the courts were true to their democracy-enhancing role.

Impeachment by a minority:

Governor Joshua Dariye vs Plateau State House of Assembly

Like that in Oyo State the case in Plateau State involved the reinstatement of 
an elected governor, who was wrongful removed from office midway into his tenure. The matter began on 2 September 2004, when Governor Joshua Dariye of Plateau was arrested in London by agents of the London Metropolitan Police on suspicion of money laundering. On the basis of this and other allegations made against Dariye, the Economic and Financial Crime Commission (EFCC), one of Nigeria's anti-corruption agencies, opened an investigation into the matter.

When Dariye was indicted the EFCC began prosecution in a Kaduna High Court but the process was halted when the court ruled that Dariye, like the other 35 state governors, enjoyed constitutional immunity from arrest and prosecution while still in office. In response, the EFCC decided to turn his file over to the Plateau State House of Assembly (The Guardian, 15 December 2005), which was constitutionally empowered to impeach the governor. When this move failed (a majority of the 24-member Plateau legislature threw their support behind the governor), many of the Plateau lawmakers were accused of corruption and picked up by the EFCC for questioning. In the confusion that followed the house could not sit for several weeks as it was unable to form a quorum. The state became ungovernable and the parties to the conflict traded accusations and counteraccusations.

In 2006 six members of the Plateau State House of Assembly, prodded by the EFCC, met at an undisclosed location and announced that they had impeached Governor Joshua Dariye, who, at the time, had already gone into hiding for security reasons. This decision was obviously a violation of the constitutional provision on impeachment, which provides that a governor can only be impeached by a two-thirds majority of all assembly members. Yet such a flagrant constitutional breach did not invite any significant response from the presidency, which is well known for its own numerous constitutional violations (Omotola 2007c), suggesting that the action had a wider political dimension.

Indeed, as was the case with the earlier impeachment of Governor Alamieyeseigha (an exercise that was also orchestrated by the EFCC and the federal government), the impeachment of Mr Dariye was widely interpreted as a political move intended to punish a governor who refused to support the 2003 re-election bid of President Olusegun Obasanjo, or allied himself with Obasanjo's arch-rival, Vice-President Atiku Abubakar.

Convinced that the motives for his impeachment were political and unconstitutional Dariye filed a suit before a high court located in Jos, the capital of Plateau State, challenging the legality of the procedure followed by the six lawmakers. Again, like Governor Ladoja of Oyo State, Dariye was ultimately restored to power by the CofA, which found that his impeachment had not strictly followed the procedures laid down in the Constitution (Ajanaku 2007). In this case, again, we can clearly see how the judiciary is helping to stabilise democracy 
and promote the rule of law. It is particularly instructive to note that since the Plateau saga no attempt to remove an elected governor has succeeded.

\section{THE JUDICIARY AND THE 2007 ELECTION}

If the phenomenon of unlawful impeachment has been largely discouraged by the prompt intervention of a vigilant and resolute judiciary the question of politicians rigging their way to power through fraudulent elections remained a challenge in 2007 and beyond. The deluge of electoral petitions that followed the 2007 elections showed that the role of the judiciary as a credible mediator in political disputes will, in the years to come, remain vital.

The divisive nature of the 2007 vote is partly explained by the high stakes involved in the election. Like the 2003 election the 2007 election was viewed as a landmark, partly because if it was conducted successfully it would mark the first 'civilian to civilian leadership change' (Ajayi 2007).

The election was also held amid fears of widespread political instability. According to Jibrin Ibrahim (2007) there were three reasons for this apprehension. The first was public awareness of the vast knowledge and repertoire of the techniques of electoral fraud and electoral violence at the disposal of the political class, which have often been used to frustrate the rights of Nigerians to elect their leaders.

The second was the willingness or capacity of INEC and the security forces to prepare adequately a level playing field for free and fair elections. The third was the growing tensions within the political class, ethno-regional zones and political parties, which have constituted the most important threat to the political stability of the country. All these tensions ultimately combined to produce a highly discredited election.

\section{THE CONDUCT OF THE 2007 ELECTION: LEGAL PROTESTS AND JUDICIAL MEDIATION}

The conduct of the election did indeed prove that Nigeria had made little progress in the very important task of cleaning up its electoral system, long tainted by electoral fraud and corruption (Suberu 2007). As widely expected, the results showed that the ruling PDP had won the presidential election and a majority of the state governorship positions, as well as the federal and state assemblies. This victory, as was the case with the 2003 elections, was procured on the back of widespread electoral malpractices and corruption.

Both international and domestic public opinion were heavily critical of the conduct and outcome of the election, which was generally regarded as 'falling 
far short of basic international and regional standards for democratic elections' (The Guardian, 24 April 2007). Despite these concerns the declared winners of the elections were duly sworn into their respective offices on 29 May 2007, leaving aggrieved aspirants with no option but to seek redress in the courts.

Consequently, the number of petitions filed before the courts in respect of the 2007 general elections reached 1250 (INEC 2007) - the highest number in the country's history and more than double the 527 petitions lodged in respect of the 2003 elections (The Punch, 10 February 2009). The surge in the number of petitions is important in itself because it may be regarded as an affirmation of confidence in the integrity of the judiciary. But more noteworthy was the actual handling of the petitions, which, as the subsequent sections of this chapter will show, demonstrated that the Nigerian judiciary was moving to consolidate and improve on its role as an agent of democracy. Again an analysis of all the petitions filed (see annexure) is clearly beyond the scope of this article, so only petitions emanating from governorship elections in six states (Anambra, Imo, Edo, Rivers Ondo, Ekiti) are considered here.

\section{Ekiti State: Kayode Fayemi vs Segun Oni}

Ekiti State is one of the five south-west states won by the PDP in 2003. In the 14 April 2007 governorship election the state was again won by the PDP, according to results announced by INEC. This victory, however, proved very controversial. Immediately after INEC announced the result the Action Congress (AC) candidate, Kayode Fayemi, who came second on INEC's list, challenged the result before the Ekiti State Elections Petitions Tribunal (ESEPT). There were two main grounds for Fayemi's complaints - that there had been serious irregularities and fraud in 63 wards in ten local government councils and that the election was marred by non-compliance with the Electoral Act (The Guardian, 18 February 2009).

After losing his appeal at the ESEPT Fayemi appealed to the CofA in Ilorin. In February 2009 the court upheld one of his two major complaints, which was enough to nullify the election of the PDP's Segun Oni. Specifically, the court found that Oni's purported election had failed substantially to comply with the 2006 Electoral Act. The second ground for complain was rejected because the AC candidate failed to prove beyond reasonable doubt his allegation of ballot-box stuffing. Consequently, the court ordered Oni to hand over the leadership of the state immediately to the Speaker of the House of Assembly, Olatunji Odeyemi, while re-runs of the elections in 10 of the 16 local government areas of the state were to be held within 90 days.

The reactions of the two protagonists showed their positive perceptions of the judiciary and, in this case, are worth noting. Immediately after the final 
judgement was read both parties expressed their willingness to accept and abide by the verdict. In his response, Oni, the PDP governor who had just been removed by the court, underlined the changing approached of politicians to the rule of law when he said: 'It is the will of God. The verdict is not a setback. I do not see the re-run as a setback because, if we do it again, we will still win. My message to the Ekiti people is that everybody should remain in a jubilant mood.' Indeed, in the days that followed both candidates conducted themselves peacefully even as they commenced preparations for the re-run.

The limit of the progress made was, however, highlighted by the violence and confusion that followed the re-run election in Ekiti, which eventually took place on 25 April 2009. Several days after the vote the results remained unknown. After disappearing for few days, fuelling speculation that she might have resigned her position under pressure, the resident electoral commissioner, Ayoka Adebayo, who had supervised the re-run, surfaced in INEC's Abuja headquarters to announce that she would return to Ekiti State to conclude the announcement of the results (The Punch, 30 April 2009).

The result that was announced when she returned to her post in Ekiti again awarded victory to the PDP, fuelling suspicion that the vote or, more correctly, the result, had been rigged. The announcement of the result led to a temporary breakdown of law and order as angry supporters of the AC clashed with PDP thugs and security agents.

Eventually the AC candidate returned to the ESEPT, complaining, again, that the result announced by INEC was a farce. This suit succeeded in October 2010, when Oni's election was nullified on the grounds of non-compliance with the Electoral Act. The AC candidate was immediately sworn in as the duly elected governor of Ekiti State.

\section{Ondo State: Mimiko vs Olusegun Agagu}

The 2007 governorship election in Ondo state, like those in other states of the federation, featured several political parties and candidates, including the incumbent PDP governor, Olusegun Agagu, who was running for a second term.

The first petition against the result was received on 15 April 2007, 24 hours after the PDP's candidate was announced as winner. The result was eventually challenged by four contestants, the most forceful being the candidate of the relatively unknown Labour Party, Olusegun Mimiko, whose petition resulted in the removal of the PDP governor from office on 22 February 2009 when the CofA, sitting in Benin, declared Mimiko to be the rightful governor of Ondo State. In reaching this conclusion the court was merely affirming the judgement of the 
lower tribunal, which had annulled the disputed poll and declared Mimiko to be the winner (The Guardian, 23 February 2009).

Like others before it, the judgement was greeted with widespread jubilation and celebration. Almost immediately after it was read Akure, the Ondo state capital, erupted in a frenzy of jubilation, with youths taking to the streets in a victory dance along major roads and drinking spots, which had been closed, reopening. Thousands of residents gathered in the streets to celebrate what one described as 'a triumph of the majority over the oppression of the minority' (The Guardian, 23 February 2009). In the end, the removal of the former Ondo State governor passed without any major political incident, except a well publicised message from the president, Umaru Musa Yar'Adua, congratulating Mimiko and assuring him of the full cooperation of his administration (ThisDay, 28 February 2009).

\section{Edo State: Adams Oshimole vs Oserheimen Osubor}

The governorship election in Edo State was also concluded on 14 April 2007 and the results remained contested several months later, with the AC candidate, Adams Oshimole, a former president of the Nigerian Labour Congress, challenging the election of Oserheimen Osunbor of the PDP. In March 2008 the Edo State Elections Petitions Tribunal upheld Oshimole's petition, thereby invalidating Osunbor's election. This decision forced the governor to file an appeal in the CofA in Benin City, which he lost on 11 November 2008 (The Punch, 13 November 2008).

Like other governors who had been removed from office by Nigeria's increasingly assertive judiciary, Professor Osunbor left the state house in Benin City within 24 hours, underlining the fact that Nigerian politicians have come to regard the power of the judiciary as a fait accompli. The conduct of the opposition in Edo State, even in the face of delayed justice, also needs to be underlined. Throughout the litigation process the party and its leaders maintained their faith in the capacity of the judiciary to deliver justice. This was underlined in Oshimole's statement when his appeal was launched in 2007:

The good news is that we are running a system that is based on the principles of separation of powers. So, the president could use INEC, police or even the army, but he does not have control over the judiciary - and there is enough evidence that a number of judicial pronouncements have embarrassed the federal government

The judiciary proved him right. 


\section{Imo State: Ikedi Ohakim vs Ifeanyi Araraume}

The 2007 election in Imo State was won by an opposition candidate, Ikedi Ohakim. Before he emerged as governor Ohakim and his party, the Progressive People's Alliance (PPA) were hardly known to Nigerians outside the state. Ohakim's popularity soared when the hitherto ruling PDP became entangled in an extralegal and potentially damaging nomination process, for which it was heavily punished by both the courts and the electorate.

The PDP's governorship primary was won by Ifeanyi Araraume, a former senator. But soon after the vote the PDP leadership replaced Araraume with another politician, Charles Ugwu, who had not stood in the primaries. Contrary to the provisions of the Electoral Act the party gave no reason for its decision. Araraume challenged his replacement in the Supreme Court, which declared it invalid, noting that, in the eyes of the law, he remained the authentic candidate. Instead of complying with the ruling the PDP withdrew from the Imo governorship election completely, leaving Araraume running without his party's support. Araraume was roundly defeated by his lesser-known challenger, Ikedi Ohakim.

Ohakim's victory was further cemented by subsequent judicial interventions. After he assumed office in 2007 his opponents went to court to challenge the result. The major challenge, ironically, came from Araraume, who pleaded with the court to annul Ohakim's election on the grounds that it had been marred by corrupt practices and violence and that he, rather than Ohakim, had won a majority of the votes cast.

Araraume also wanted the court to order by-elections in nine local government areas where the alleged elections had, in fact, not taken place, claiming that the results declared for those areas had been fabricated by INEC (The Guardian, 24 March 2009). In the end, the Imo State Elections Petitions Tribunal and the AC ruled that Araraume's petition lacked merit in every respect and that he had failed to prove his case convincingly (Saturday Tribune, 8 March 2008), putting an end to an apparent plot by the PDP to regain the state through the back door.

\section{Rivers State: Chibuike Amaechi vs Celestine Omehia}

The election dispute in Rivers State was similar to that in Imo State in that Chibuike Amaechi, the PDP candidate who won the party primary, was replaced by another candidate, Celestine Omehia, who had not participated in the primary. Again the party gave no reason for the change, although Amaechi was subsequently indicted for corruption by an administrative panel set up by the federal government (Daily Sun, 11 October, 2007). 
Unlike in the Imo case, Omehia went on to contest and win the election for the party, but instead of uniting the party, his victory only served to boost Amaechi's determination to demand justice. Thus, immediately after the gubernatorial election he challenged Omehia's election in court. The grounds for his appeal, not unexpectedly, were that the party had failed to comply with s 34(1) of the Electoral Act 2006, which provides that a political party must give cogent and verifiable reasons for substituting a candidate. The PDP, angered by Amaechi's audacity in challenging the authority of 'the party' in court suspended him.

Initially Amaechi's substitution was upheld by both the High Court and the CofA, which declared the substitution lawful. The CofA went further, citing Amaechi's indictment by a federal government administrative panel as a further justification. However, this judicial anomaly was subsequently corrected by the Nigerian Supreme Court, which, in a unanimous decision on 25 October 2007, concluded that the PDP had not provided cogent and verifiable reasons for the substitution, as required by law.

The court also held that the claim that Amaechi had been indicted by a federal government administrative panel was untenable because 'there is no indictment known to the law against the appellant, no court of law has pronounced the appellant guilty of any criminal offences as to justify his unlawful exclusion from the election' (The Guardian, 26 October 2007). Consequently, the court ordered that Omehia immediately vacate office and Amaechi be sworn in as the rightful governor of Rivers State (The Guardian, 26 October 2007).

The response of the PDP hierarchy to this embarrassing judgement came through President Yar'Adua. In a press statement released by his spokesman the president directed all 'relevant authorities and agencies to take immediate steps to implement the orders of the Supreme Court'. He also 'called on all parties to the suit to respect and abide by the ruling ... and to accept the judgment in good faith' (The Guardian, 26 October 2007). The governor immediately handed over power, saying he accepted the judgement as 'the the will of God', while calling on his supporters and the people of the state to 'cooperate with the incoming administration' in order to 'maintain the existing peace, which, he observed, was necessary for development of the state' (The Guardian, 27 October 2007).

\section{Anambra State: Peter Obi vs Andy Uba and INEC}

The 2007 governorship elections took place simultaneously in all 36 states of the federation, including Anambra State, where Peter Obi had become governor in March 2006 after successfully challenging the election of Chris Ngige, wrongfully declared by INEC to be the winner of the April 2003 governorship election. Consequently Obi had only been in office for 12 months and, believing his tenure 
was four years, he had not stood in the 2007 election. The election was won by Andy Uba of the PDP, a former aide and well-known ally of the then-outgoing president, Olusegun Obasanjo.

The key question was when Governor Obi could be said to have completed his term as governor. Was it April 2007 or March 2010? Not unexpectedly Obi contended that his term would end in March 2010. Without resolving this constitutional issue satisfactorily INEC went ahead with the governorship polls in Anambra on 14 April 2007.

Immediately after the election Obi once again headed to the courts. This time his port of call was the Supreme Court, which he asked to determine whether INEC's decision to organise the election had been correct. In taking the matter to court he was supported by a large section of the Nigerian Bench and, indeed, the public, who argued that Obi should have been allowed to remain in office for four years in line with the wishes of the voters and with the law.

Some lawyers, such as the well-known democracy and human rights activist, Gani Fawehinmi, argued that the CofA should be the final court in matters relating to the tenure of a governor and that the Supreme Court should not have entertained Obi's case in the first instance. But Obi's suit was simply to seek an interpretation of the provisions of the Constitution as it affected his tenure and, strictly speaking, did not challenge the election of any other person - he was not asking for the nullification of the April 2007 election.

In the event, the Supreme Court ruled that Obi's tenure should extend to March 2010 and the Anambra State Elections Petition Tribunal nullified Uba's win, giving vivid expression to an opinion indirectly expressed by the apex court that the holding of an election when the tenure of the occupant of an office has not expired was 'an action in error' (The Guardian, 15 June 2007).

\section{CONCLUSION}

One of the basic requirements for the survival and prosperity of a liberal democratic state is the presence of strong and independent oversight institutions, one of which is the judiciary (Mbanefo 1975; Walraven \& Thiriot 2002). Competent and independent judiciaries are, in many ways, central to democracy (Leonard 2009, p 8). A good judiciary will not only check the abuse of power by government (Davies 1990; Ige \& Ige 2006) it will also be capable of managing the intra-elite disputes and/or conflicts which are bound to result from the competition for power and economic resources involved in party politics in a multiethnic society (Suberu 2001).

Many of Nigeria's democratic failings in the past have been the result of the inability to construct an impartial and honest judiciary that commands the respect 
and confidence of most of the members of its fractious political class and its deeply divided population (Olurode 1990; Unobe 1990). Since 1999, when Nigeria moved from a military autocracy to a multiparty democracy, some carefully crafted legal and administrative tinkering has transformed its judiciary from an extension of the executive into an impartial and credible arbiter of political disputes.

Indeed, from our review of the 2003 and 2007 elections and the series of political disputes that followed them, notably those involving state governors wrongfully removed from office, we can see clearly that, while the Nigerian judiciary has not succeeded in introducing a culture of free and fair elections or solved the problem of judicial corruption, or even enthroned a flawless framework for electoral justice (Omotola 2010a; 2010b), it has undergone a major transformation, becoming a reliable partner in Nigeria's historic struggle for a fairer electoral process.

To quote the country's former vice-president, who won several legal victories in his political battles with former-president Olusegun Obasanjo, 'even though major elections have continued to be dogged by widespread irregularities, fraud and violence ... all hope has not been lost as the current role of the judiciary has been enough saving grace' (ThisDay, 15 February 2009).

Put differently, the political consequences of recent reforms of the judiciary have been significant. Although Nigeria continues to be plagued by serious intraelite wrangling, very often resulting in bloody political conflicts, the increasing willingness of political elites to seek judicial avenues for the resolution of conflicts has helped to maintain political stability and social harmony. Nigerian politicians are increasingly resorting to the courts to resolve their differences and have come to see an acceptance of court verdicts, in whichever direction they go, as being in their long-term interest. This largely explains the longevity of the Fourth Republic. 


\section{ANNEXURE}

Summary of the April 2007 governorship elections: Grounds for and outcomes of appeals

\begin{tabular}{|c|c|c|c|c|c|}
\hline State & Winner & $\begin{array}{l}\text { Main } \\
\text { appellant }\end{array}$ & $\begin{array}{l}\text { Plea/grounds } \\
\text { for appeal }\end{array}$ & Decision & Outcome \\
\hline Abia & PPA & $\begin{array}{l}\text { PDP, } \\
\text { APGA }\end{array}$ & $\begin{array}{l}\text { Non- } \\
\text { compliance } \\
\text { with the } \\
\text { Electoral Act; } \\
\text { membership } \\
\text { of secret cult } \\
\text { and non- } \\
\text { resignation } \\
\text { from office as } \\
\text { required by } \\
\text { law }\end{array}$ & $\begin{array}{l}\text { Petition upheld } \\
\text { and election } \\
\text { annulled } \\
\text { by tribunal, } \\
\text { but later } \\
\text { revalidated by } \\
\text { Court of Appeal } \\
\text { (CofA) }\end{array}$ & $\begin{array}{l}\text { PPA gov to } \\
\text { remain in office } \\
\text { until } 2011\end{array}$ \\
\hline Adamawa* & PDP & $\mathrm{AC}$ & $\begin{array}{l}\text { Unlawful } \\
\text { exclusion of } \\
\text { AC candidate } \\
\text { from election } \\
\text { by INEC }\end{array}$ & $\begin{array}{l}\text { Appeal upheld } \\
\text { by tribunal \& } \\
\text { CofA. Election } \\
\text { voided }\end{array}$ & $\begin{array}{l}\text { Re-run election } \\
\text { held \& won by } \\
\text { PDP }\end{array}$ \\
\hline A/Ibom & PDP & ANPP & $\begin{array}{l}\text { Obstruction } \\
\text { by INEC; } \\
\text { electoral } \\
\text { malpractices; } \\
\text { winner had } \\
\text { been indicted } \\
\text { for fraud }\end{array}$ & $\begin{array}{l}\text { Appeal rejected } \\
\text { by both tribunal } \\
\text { and CofA for } \\
\text { lack of merit }\end{array}$ & $\begin{array}{l}\text { PDP gov to } \\
\text { continue in } \\
\text { office until } 2011\end{array}$ \\
\hline Bauchi & ANPP & $\mathrm{AC}$ & $\begin{array}{l}\text { Election } \\
\text { marred by } \\
\text { fraud \& } \\
\text { malpractice }\end{array}$ & $\begin{array}{l}\text { Not available } \\
\text { (NA) }\end{array}$ & $\begin{array}{l}\text { ANPP gov to } \\
\text { continue in } \\
\text { office until } 2011\end{array}$ \\
\hline Bayelsa* & PDP & $\mathrm{AC}$ & $\begin{array}{l}\text { Irregularities, } \\
\text { violence and } \\
\text { disparities } \\
\text { between } \\
\text { voters' } \\
\text { register and } \\
\text { votes cast }\end{array}$ & $\begin{array}{l}\text { Petition rejected } \\
\text { by tribunal for } \\
\text { lack of evidence } \\
\text { but later upheld } \\
\text { by CofA, which } \\
\text { voided the } \\
\text { election }\end{array}$ & $\begin{array}{l}\text { Re-run election } \\
\text { held \& won by } \\
\text { PDP }\end{array}$ \\
\hline Benue & PDP & $\begin{array}{l}\text { ANPP, } \\
\text { AC }\end{array}$ & $\mathrm{NA}$ & N A & N A \\
\hline
\end{tabular}




\begin{tabular}{|c|c|c|c|c|c|}
\hline Bornu & ANPP & AC & $\begin{array}{l}\text { Election } \\
\text { marred by } \\
\text { fraud }\end{array}$ & $\begin{array}{l}\text { Appeal rejected } \\
\text { by tribunal } \\
\text { and CofA for } \\
\text { being lodged } \\
\text { late \& lack of } \\
\text { jurisdiction }\end{array}$ & $\begin{array}{l}\text { Incumbent } \\
\text { ANPP gov to } \\
\text { continue in } \\
\text { office until } 2011\end{array}$ \\
\hline C/River* & PDP & $\begin{array}{l}\text { ANPP, } \\
\text { AC, ARP, } \\
\text { PPA }\end{array}$ & $\begin{array}{l}\text { Irregularities } \\
\& \text { non- } \\
\text { compliance } \\
\text { with electoral } \\
\text { law }\end{array}$ & $\begin{array}{l}\text { Appeal rejected } \\
\text { by tribunal, } \\
\text { but upheld by } \\
\text { CofA; election } \\
\text { nullified }\end{array}$ & $\begin{array}{l}\text { Re-run election } \\
\text { held and won } \\
\text { by PDP gov }\end{array}$ \\
\hline Delta & PDP & AC, DPP & $\begin{array}{l}\text { Irregularities } \\
\& \text { unlawful } \\
\text { exclusion } \\
\text { of CofA } \\
\text { candidate by } \\
\text { INEC }\end{array}$ & $\begin{array}{l}\text { Tribunal } \\
\text { dismissed } \\
\text { petition \& } \\
\text { declined } \\
\text { jurisdiction, } \\
\text { CofA now } \\
\text { before the } \\
\text { appeal court }\end{array}$ & $\begin{array}{l}\text { Incumbent to } \\
\text { continue in } \\
\text { office until } 2011\end{array}$ \\
\hline Ebonyi & PDP & ANPP & $\begin{array}{l}\text { Electoral } \\
\text { malpractice, } \\
\text { irregularities } \\
\text { and violence }\end{array}$ & $\begin{array}{l}\text { Appeal rejected } \\
\text { by tribunal } \\
\text { for want of } \\
\text { evidence }\end{array}$ & $\begin{array}{l}\text { Incumbent to } \\
\text { continue in } \\
\text { office until } 2011\end{array}$ \\
\hline$E^{2 d o *}$ & PDP & $\mathrm{AC}$ & $\begin{array}{l}\text { Irregularities } \\
\text { and non- } \\
\text { compliance } \\
\text { with Electoral } \\
\text { Act }\end{array}$ & $\begin{array}{l}\text { Appeal upheld } \\
\text { by tribunal and } \\
\text { CofA; appellant } \\
\text { declared } \\
\text { winner }\end{array}$ & $\begin{array}{l}\text { Appellant } \\
\text { sworn in as } \\
\text { governor to } \\
\text { replace PDP } \\
\text { gov }\end{array}$ \\
\hline Ekiti $^{*}+$ & PDP & AC & $\begin{array}{l}\text { Irregularities } \\
\text { and fraud } \\
\text { in } 63 \text { wards } \\
\text { in } 10 \text { LGAs } \\
\text { and non- } \\
\text { compliance } \\
\text { with Electoral } \\
\text { Act }\end{array}$ & $\begin{array}{l}\text { Appeal upheld } \\
\text { by both tribunal } \\
\text { and CofA; re- } \\
\text { run held ending } \\
\text { in stalemate }\end{array}$ & $\begin{array}{l}\text { Acting } \\
\text { governor to } \\
\text { remain in office } \\
\text { until winner } \\
\text { emerges }\end{array}$ \\
\hline Enugu & PDP & $\begin{array}{l}\text { DPP, AC, } \\
\text { PPA, AP, } \\
\text { LP }\end{array}$ & $\begin{array}{l}\text { Electoral } \\
\text { fraud } \\
\text { and non- } \\
\text { compliance } \\
\text { with Electoral } \\
\text { Act }\end{array}$ & $\begin{array}{l}\text { Appeal upheld } \\
\text { by tribunal } \\
\text { but rejected by } \\
\text { CofA }\end{array}$ & $\begin{array}{l}\text { Incumbent PDP } \\
\text { gov to continue } \\
\text { in office until } \\
2011 .\end{array}$ \\
\hline
\end{tabular}




\begin{tabular}{|c|c|c|c|c|c|}
\hline Gombe & PDP & $\mathrm{AC}$ & $\begin{array}{l}\text { Electoral } \\
\text { fraud }\end{array}$ & $\begin{array}{l}\text { Appeal rejected } \\
\text { by tribunal and } \\
\text { CofA for want } \\
\text { of evidence and } \\
\text { being status } \\
\text { barred }\end{array}$ & $\begin{array}{l}\text { Incumbent } \\
\text { PDP governor } \\
\text { to continue } \\
\text { in office until } \\
2011 .\end{array}$ \\
\hline $\operatorname{Imo}^{* *}$ & PPA & $\begin{array}{l}\text { PDP, } \\
\text { APGA, } \\
\text { AC }\end{array}$ & $\begin{array}{l}\text { Fraud and } \\
\text { irregularities }\end{array}$ & $\begin{array}{l}\text { Appeal rejected } \\
\text { by tribunal and } \\
\text { CofA for want } \\
\text { of evidence }\end{array}$ & $\begin{array}{l}\text { PPA gov to } \\
\text { remain in } \\
\text { office pending } \\
\text { Supreme Court } \\
\text { decision }\end{array}$ \\
\hline Jigawa & PDP & $\begin{array}{l}\text { ANPP, } \\
\text { AC }\end{array}$ & N A & N A & N A \\
\hline Kaduna & PDP & $\begin{array}{l}\text { ANPP, } \\
\text { DPP }\end{array}$ & $\begin{array}{l}\text { Fraud and } \\
\text { irregularities }\end{array}$ & $\begin{array}{l}\text { Petition rejected } \\
\text { by tribunal, } \\
\text { now before } \\
\text { CofA }\end{array}$ & $\begin{array}{l}\text { PDP gov to } \\
\text { remain in office } \\
\text { until } 2011\end{array}$ \\
\hline Kano & ANPP & PDP & $\begin{array}{l}\text { Irregularities } \\
\text { and winner } \\
\text { unqualified } \\
\text { for office } \\
\text { having been } \\
\text { indicted for } \\
\text { fraud }\end{array}$ & $\begin{array}{l}\text { Petition rejected } \\
\text { for want of } \\
\text { proof and } \\
\text { administrative } \\
\text { indictment not } \\
\text { grounds for } \\
\text { disqualification }\end{array}$ & $\begin{array}{l}\text { ANPP gov to } \\
\text { remain in office } \\
\text { until } 2011\end{array}$ \\
\hline Katsina & PDP & ANPP & $\begin{array}{l}\text { Corrupt } \\
\text { practices; } \\
\text { over-voting } \\
\text { and non- } \\
\text { compliance } \\
\text { with Electoral } \\
\text { Act }\end{array}$ & $\begin{array}{l}\text { Petition } \\
\text { dismissed by } \\
\text { tribunal for } \\
\text { insufficient } \\
\text { evidence; now } \\
\text { before CofA }\end{array}$ & $\begin{array}{l}\text { PDP gov to } \\
\text { continue in } \\
\text { office until } \\
\text { CofA rules }\end{array}$ \\
\hline Kebbi & PDP & ANPP & $\begin{array}{l}\text { Winner } \\
\text { not duly } \\
\text { nominated by } \\
\text { his party and } \\
\text { unqualified } \\
\text { to stand for } \\
\text { election }\end{array}$ & $\begin{array}{l}\text { Appeal upheld } \\
\text { by tribunal } \\
\text { but rejected by } \\
\text { CofA }\end{array}$ & $\begin{array}{l}\text { PDP gov will } \\
\text { remain in office } \\
\text { until } 2011\end{array}$ \\
\hline Kwara & PDP & $\mathrm{AC}$ & INEC & $\begin{array}{l}\text { Appeal rejected } \\
\text { by tribunal and } \\
\text { now before } \\
\text { CofA }\end{array}$ & $\begin{array}{l}\text { AC gov to } \\
\text { continue in } \\
\text { office until } 2011\end{array}$ \\
\hline
\end{tabular}




\begin{tabular}{|c|c|c|c|c|c|}
\hline Lagos & AC & $\begin{array}{l}\text { DPA, } \\
\text { DPP }\end{array}$ & $\begin{array}{l}\text { Electoral } \\
\text { fraud and } \\
\text { irregularities }\end{array}$ & $\begin{array}{l}\text { Appeal rejected } \\
\text { by tribunal \& } \\
\text { CofA; election } \\
\text { upheld }\end{array}$ & $\begin{array}{l}\text { AC gov to } \\
\text { continue in } \\
\text { office until } 2011\end{array}$ \\
\hline Nassaraw & PDP & $\begin{array}{l}\text { PDP, } \\
\text { DPA }\end{array}$ & $\begin{array}{l}\text { Irregularities } \\
\text { and non } \\
\text {-compliance } \\
\text { with electoral } \\
\text { law }\end{array}$ & $\begin{array}{l}\text { Petition } \\
\text { dismissed by } \\
\text { tribunal \& } \\
\text { CofA for lack of } \\
\text { evidence }\end{array}$ & $\begin{array}{l}\text { PDP gov to } \\
\text { remain in office } \\
\text { until } 2011\end{array}$ \\
\hline Niger & PDP & ANPP & $\begin{array}{l}\text { Irregularities } \\
\text { \& fraud }\end{array}$ & $\begin{array}{l}\text { Appeal rejected } \\
\text { by tribunal \& } \\
\text { CofA; election } \\
\text { upheld }\end{array}$ & $\begin{array}{l}\text { Incumbent gov } \\
\text { to continue in } \\
\text { office until } 2011\end{array}$ \\
\hline Ogun & PDP & ANPP & $\begin{array}{l}\text { Improper } \\
\text { substitution } \\
\text { by the PDP of } \\
\text { the petitioner } \\
\text { with the } \\
\text { winner } \\
\text { and non- } \\
\text { compliance } \\
\text { with Electoral } \\
\text { Act }\end{array}$ & $\begin{array}{l}\text { Appeal rejected } \\
\text { by tribunal } \\
\text { on technical } \\
\text { grounds; CofA } \\
\text { orders a retrial } \\
\text { by tribunal } \\
\text { after appellants } \\
\text { alleged bias }\end{array}$ & $\begin{array}{l}\text { Litigation } \\
\text { at tribunal } \\
\text { continues }\end{array}$ \\
\hline Ondo** & PDP & LP & $\begin{array}{l}\text { Electoral } \\
\text { fraud; } \\
\text { irregularities } \\
\text { and non- } \\
\text { compliance } \\
\text { with Electoral } \\
\text { Act }\end{array}$ & $\begin{array}{l}\text { Appeal upheld } \\
\text { by tribunal \& } \\
\text { CofA; petitioner } \\
\text { declared } \\
\text { winner }\end{array}$ & $\begin{array}{l}\text { Appellant } \\
\text { sworn in as gov } \\
\text { to replace PDP } \\
\text { gov }\end{array}$ \\
\hline Osun & PDP & AC & $\begin{array}{l}\text { Electoral } \\
\text { fraud; } \\
\text { irregularities } \\
\text { and non- } \\
\text { compliance } \\
\text { with Electoral } \\
\text { Act }\end{array}$ & $\begin{array}{l}\text { Appeal rejected } \\
\text { by tribunal but } \\
\text { CofA orders } \\
\text { retrial by } \\
\text { tribunal after } \\
\text { appellants } \\
\text { allege bias }\end{array}$ & $\begin{array}{l}\text { Litigation } \\
\text { continues at } \\
\text { tribunal }\end{array}$ \\
\hline Оуо & PDP & $\begin{array}{l}\text { ANPP, } \\
\text { AC }\end{array}$ & $\begin{array}{l}\text { Irregularities } \\
\text { and violence } \\
\text { (in } 12 \text { of } 30 \\
\text { LGAs) }\end{array}$ & $\begin{array}{l}\text { Appeal rejected } \\
\text { by tribunal \& } \\
\text { CofA; election } \\
\text { upheld }\end{array}$ & $\begin{array}{l}\text { PDP gov to } \\
\text { remain in office } \\
\text { until } 2011\end{array}$ \\
\hline
\end{tabular}




\begin{tabular}{|c|c|c|c|c|c|}
\hline Plateau & PDP & $A C$ & $\begin{array}{l}\text { Irregularities; } \\
\text { violence } \\
\text { and non- } \\
\text { compliance } \\
\text { with Electoral } \\
\text { Act }\end{array}$ & $\begin{array}{l}\text { Petition rejected } \\
\text { by tribunal } \\
\text { \& CofA for } \\
\text { coming too late }\end{array}$ & $\begin{array}{l}\text { PDP gov } \\
\text { to remain in } \\
\text { office until } 2011\end{array}$ \\
\hline Rivers** & PDP & PDP & $\begin{array}{l}\text { Electoral } \\
\text { fraud; } \\
\text { irregularities }\end{array}$ & $\begin{array}{l}\text { Petition } \\
\text { upheld by } \\
\text { Supreme Court; } \\
\text { petitioner } \\
\text { declared } \\
\text { rightful winner } \\
\text { of the elections }\end{array}$ & $\begin{array}{l}\text { Incumbent PDP } \\
\text { gov removed } \\
\text { and replaced } \\
\text { by petitioner }\end{array}$ \\
\hline Sokoto* & PDP & DPP & $\begin{array}{l}\text { Improper } \\
\text { substitution } \\
\text { by PDP of } \\
\text { the petitioner } \\
\text { by the } \\
\text { winner; non- } \\
\text { compliance } \\
\text { with Electoral } \\
\text { Act }\end{array}$ & $\begin{array}{l}\text { Petition rejected } \\
\text { by tribunal } \\
\text { but upheld by } \\
\text { CofA; election } \\
\text { voided for non- } \\
\text { qualification } \\
\text { and massive } \\
\text { irregularities. }\end{array}$ & $\begin{array}{l}\text { Re-run election } \\
\text { held and won } \\
\text { by PDP gov }\end{array}$ \\
\hline Taraba & PDP & $\mathrm{AC}$ & $\begin{array}{l}\text { Winner } \\
\text { nominated by } \\
\text { both ANPP \& } \\
\text { PDP; not duly } \\
\text { nominated; } \\
\text { had no } \\
\text { running mate; } \\
\text { electoral } \\
\text { malpractice }\end{array}$ & $\begin{array}{l}\text { Petition rejected } \\
\text { by tribunal for } \\
\text { lack of merit; } \\
\text { now before } \\
\text { CofA }\end{array}$ & $\begin{array}{l}\text { PDP gov to } \\
\text { continue in } \\
\text { office until } \\
\text { CofA rules }\end{array}$ \\
\hline Yobe & PDP & ANPP & $\begin{array}{l}\text { Winner was } \\
\text { not qualified } \\
\text { having been } \\
\text { indicted } \\
\text { for fraud; } \\
\text { failed to } \\
\text { resign before } \\
\text { contesting } \\
\text { election and } \\
\text { tendered } \\
\text { falsified } \\
\text { documents }\end{array}$ & $\begin{array}{l}\text { Appeal rejected } \\
\text { by tribunal \& } \\
\text { CofA; election } \\
\text { upheld }\end{array}$ & $\begin{array}{l}\text { ANPP } \\
\text { governor to } \\
\text { remain in office } \\
\text { until } 2011\end{array}$ \\
\hline
\end{tabular}




\begin{tabular}{|c|c|c|c|c|c|}
\hline Zamfara & ANP & PDP & $\begin{array}{l}\text { Gov not duly } \\
\text { nominated } \\
\text { by his party } \\
\text { and so not } \\
\text { qualify to run; } \\
\text { petitioner } \\
\text { excluded } \\
\text { from election; } \\
\text { irregularities } \\
\text { and non- } \\
\text { compliance } \\
\text { with electoral } \\
\text { law }\end{array}$ & $\begin{array}{l}\text { Petition rejected } \\
\text { by both tribunal } \\
\text { and CofA }\end{array}$ & $\begin{array}{l}\text { ANPP gov to } \\
\text { remain in office } \\
\text { until } 2007\end{array}$ \\
\hline
\end{tabular}

Source: Comprehensive review of Nigerian dailies from 2003 to 2010 carried out by the author

* State where election has been nullified by the court and re-run. All these cases produced victory for the incumbent PDP

*+ Election has been nullified by the court and re-run took place but ended in a political stalemate

** Court decision led to a change of government after candidates who INEC had declared elected were ordered to vacate their office in favour of their rivals

Abdul-Razaq, T. 2005. 'Election Petitions and the Politics of the Judiciary: The General Elections of 1983'. In A A Akinsanya \& J A Ayoade (eds). Readings in Nigerian Government and Politics. Ijebu-Ode: Gratia Associates International. Aderibigbe, Y. 2001. 'Political Associations Raise Stakes for 2003 Polls'. The Guardian, 12 January.

Agbo, O F. 2008. 'The Justice System in Nigeria Stinks as the Education Sector Goes Steadily Down'.

TheNews, Lagos, 28 July.

Ajanaku, A. 2007. 'Fourth Republic: The Judicial Landmarks'. The Guardian, 28 October.

Ajayi, K. 2006. 'Security Forces, Electoral Conduct and the 2003 General Elections in Nigeria'. Journal of Social Sciences 13(1).

2007. 'Election Administration in Nigeria and the Challenge of the 2007 elections'. The Social Sciences 2(2).

Davies, E A. 1990. 'The Independence of the Judiciary in Nigeria: Problems and Prospects'. African Study Monograph 10(3), February.

Enweremadu, U D. 2006. 'Lutte anti-corruption et politique au Nigeria sous la quatrième République: 1999-2006'. Unpublished PhD thesis, Centre d'Etudes 
d'Afrique noire/Institut d'Etudes Politiques de Bordeaux, Université Montesquieu Bordeaux.

Federal Republic of Nigeria. 1999. 'The 1999 Constitution of the Federal Republic of Nigeria'. Abuja.

— 2003. 'Nigeria Governance and Corruption Survey Study: Overall Summary Report'. Abuja, June.

- 2004. 'Report of the Judicial Panel on the Reform/Reorganisation of the Judiciary'. Abuja.

Ibrahim, J. 2007. 'Prospects for Credible Elections in Nigeria'. The Nordic African Institute 16(22), 24 January.

Ige, A \& I Ayodeji. 2006. 'The Imperative of a Virile Judiciary in Democratic Governance'. In F A D Oyekanmi \& S O Omolou (eds). Society and Governance: The Quest for Legitimacy in Nigeria. Lagos: Irede Printers Ltd.

Jakada, T J. 2003. 'Election Losers and Cowboy Posture'. New Nigeria, 28 May.

Jeter, H. 2003. 'Reflections on the 2003 Elections'. The Guardian, 16 April.

Leonard, D K. 2009. 'Elections and Conflict in Africa: An Introduction'. Journal of African Elections 8(1), June.

Lewis, P. 2003. 'Nigeria: Elections in a Fragile Regime'. Journal of Democracy 14(3).

Mbanefo, L. 1975. 'The Role of the Judiciary in Nigeria Now and in the Future'. Public lecture delivered in Lagos, 29 September.

Nwabueze, O B. 1992. Military Rule and Constitutionalism. Ibadan: Spectrum Law Publishing.

Obassa, S. 2003. 'Civilian to Civilian Transfer: The Journal So Far'. New Nigeria Weekly, Lagos, 19 April.

Ogunsanwo, A. 2006. 'Keynote Address'. In F A D Oyekanmi \& O Soyombo (eds). Society and Governance: The Quest for Legitimacy in Nigeria. Lagos: Irede Printers Ltd.

Oko, O. 2002. 'Subverting the Scourge of Corruption in Nigeria: A Reform Prospectus'. Journal of International Law and Politics 34.

— 2005. 'Seeking Justice in Transitional Societies: An Analysis of the Problems and Failures of the Judiciary in Nigeria'. Brooklyn Journal of International Law 31(9).

Ologbenla, D. 2003. 'Political Instability, Conflict and the 2003 General Elections'. In R Anifowose \& T Babawale (eds). General Elections and Democratic Consolidation in Nigeria. Lagos: Frankad Publishers.

Olurode, L. 1990. A Political Economy of Nigeria's 1983 Elections. Lagos: John West Publications Ltd.

Omotola, J S. 2007a. 'Democracy and Constitutionalism in Nigeria Under the Fourth Republic, 1999-2007'. Africana: A Journal of Ideas on Africa and the African Diaspora 2(2). 
- 2007b. 'Godfathers and the 2007 Nigerian General Elections'. Journal of African Elections 6(2), October.

- - 2007c. 'Politics of Impeachment and Democratization in Nigeria, 1999-2007: The Oyo State Experience'. International Journal of Social and Management Sciences 2(1).

—. 2010a. 'Elections and Democratic Transitions in Nigeria under the Fourth Republic'. African Affairs 109(437).

. 2010b. 'Mechanisms of post-election conflict resolution in Africa's "new" democracies'. African Security Review. Available at: http:/ / www.informaworld. $\mathrm{com} / \mathrm{smpp} /$ title $\sim \mathrm{db}=\mathrm{all} \sim$ content $=\mathrm{t} 919213844 \sim \mathrm{tab}=\mathrm{issueslist} \sim$ branches $=19$ v19 19(2).

Otteh, C J. 2004. 'Restoring the Nigerian Judiciary to Its Pride of Place'.The Guardian, Lagos, 13 April.

Suberu, R. 2001. Federalism and ethnic conflict in Nigeria. Washington, DC: United States Institute of Peace Press.

—. 2007. 'Nigeria's Muddled Elections'. Journal of Democracy 18(4).

—. 2008. 'The Supreme Court and Federalism in Nigeria'. Journal of Modern African Studies 46(3).

Unobe, E A. 1990. 'Partisan Judiciary and Political Instability in Nigeria'. In I E S Amdi \& W Hinjari (eds). Party Systems, Democracy and Political Stability in Nigeria. Zaria: Nigerian Political Science Association.

United Nations Office on Drugs and Crime. 2003. Strengthening Judicial Integrity and Capacity in Nigeria: Terminal Evaluation Report. Vienna: United Nations Office on Drugs and Crime.

- 2004. Assessment of Justice System Integrity and Capacity in Three Nigerian States: Technical Research Report. Vienna: United Nations Office on Drugs and Crime.

Van Walraven, K \& C Thiriot Celine. 2002. Democratization in Sub-Saharan Africa: Transitions and Turning Points: An Overview of the Literature. African Studies Centre Research Report 65. 